\title{
Food Security Status of People with Disabilities in Selassie Kebele, Hawassa Town, Southern Ethiopia
}

\author{
Fiseha Endale $^{1}$ and Degefa Tolossa ${ }^{2}$
}

\begin{abstract}
The paper is about the food security of people with disabilities in Hawassa town. The situations of people with physical, vision, and speech and/or hearing type of disabilities were studied on the basis of Key Informant Interviews, Focus Group Discussion and conducting exploratory household questionnaire survey. Food security indicators such as income, food self-sufficiency and frequency of meals per days were assessed. Coping Strategy Index (CSI) was the technique employed to assess food security status at household level. It was found that people with disabilities mostly depend upon family members' compassion and charity to sustain their livelihoods. Likewise, a lack of awareness, self-interest, family and community members' lack of knowledge and misperceived attitudes have prevented people with disabilities from being independent in their sources of livelihood and attaining food security. Disabilities made them somehow powerless in decision making. Majority of the sample respondents were chronically food insecure. Individuals with physical type of disabilities accounted for the largest proportion of those who are illiterate as well as unemployed. The same group was more vulnerable to food insecurity than their counterparts with other types of disabilities. PWDs cope with food shortage by limiting portion of size at meal, eating less preferred and cheap foods and begging on the streets. Improving the food security of PWDs should receive the attention of all concerned actors. It is important to create jobs that fit to the situation of PWDs, access them to training, credit, marketing facilities and treatment and increasing public awareness about the situations of the PWDs.
\end{abstract}

Keywords: disability, food security, coping mechanisms, PWDs, Hawassa

\footnotetext{
${ }^{1}$ Expert in Food Security Studies

${ }^{2}$ Associate Professor, College of Development Studies, Addis Ababa University
} 


\section{Introduction}

Over a billion people live with a disability in the world, of which $80 \%$ reside in developing countries (UNCRPD 2011). Most of the People With Disabilities (PWDs) in developing countries do not have access to rehabilitation services mainly due to a lack of resources (World Health Organization /WHO/ 2010). The state of PWDs in Ethiopia is even more tragic and severe because of the presence of diversified pre and post-natal disabling factors such as infectious diseases, difficulties contingent to delivery, malnutrition, harmful cultural practices, lack of proper child care and management, civil war, absence of early primary and secondary preventive actions, and periodic droughts and subsequent famines (JICA 2002).

Despite the strong links between poverty and disability, PWDs are still largely invisible in global development efforts. Although the MDGs have achieved remarkable success in reducing poverty, many people with disabilities have benefited little from this progress. Disability in development remains stuck in the 'special needs' section of targeted projects on health, education and welfare (DFID, 2014).

There is two-way linkage between food insecurity and poor livelihood situation, and disabilities. Poverty and chronic food insecurity may lead to disability through poor quality of life, malnutrition and lack of access to health services. Likewise, disability can lead to poverty and food insecurity through lack of employment and education opportunities, limited access to health and social services (Edge, 2013).

According to the Ethiopian Federation of Persons with Disabilities (EFPD) (2001), there are various types of disabilities with different prevalence rates. For instance, disabilities related to motor disorder, visual impairment, and hearing impairment had a relatively high prevalence rates accounting for $41.2 \%, 30.4 \%$, and $14.9 \%$, respectively. Food security and vulnerability assessments in Ethiopia have traditionally focused on rural areas. The rural food insecure population rose from 2 million people in 1995 to about 14 million in 2008 (EFPD 2001). As the population in urban areas has been on the increase and given the economic shocks, food insecurity in urban areas has become a major concern (WFP 2009; Degefa 2010).

While household food insecurity has been examined in various sociodemographic populations like children, gender, immigrants and welfare populations, little is known about food insecurity among PWDs (She and Livermore 2007). It is assumed that people with disabilities and their families are more vulnerable to food insecurity than their counterparts without disabilities. People with disabilities are constrained by economic resources due to their higher poverty rate and lower employment rate compared to those without disabilities (Weathers 2005). 
Tirusew (2000) points out that PWDs have for many years been despaired, isolated and discriminated. Discrimination, above all, is a distinguishing mark all persons with disability have been suffering from all over the world in general, and in Ethiopia in particular. There are a remarkable number of persons with disabilities in Ethiopia. However, their problems and the scope of actual problems that they face in their everyday lives have not been fully investigated.

A large number of PWDs in Selassie kebele of Hawassa city were found to be unemployed while some engaged in various types of petty trading and work as daily laborers. A few of formally employed persons with different forms of disabilities work in private and government organizations. Among the total population of the city of Hawassa $(313,564)$, according to CSA (2014), 1607 are people with various types of disabilities (980 male and 627 female). Some 590 households of the city inhabitants have one or more members of PWDs.

Hawassa city has been recording a continuous multi-faceted development over years. In contrast, there also has been a high likelihood of increasing number of marginalized and urban-poor and food insecure people. Accordingly, PWDs in Addis Ketema Sub-City, Selassie kebele are good instances in terms of low standard of living they lead in line with enormous difficulties they face in their day-to-day livelihood activities. Although disability as one socio-economic problem has received the attention of many scholars, the nexus between food security and PWDs was the little investigated issue. This research attempts to contribute to endeavors of bridging the knowledge gap on the topic. Hence, the paper assesses and analyzes household food security status of people with disabilities. We believe that the study would contribute to the understanding of those who involve in practices of improving the quality of life, and food security among PWDs.

The core purpose of this study was to explore the food security status of households with PWDs in Seleassie Kebele of Hawassa city. The research focused on three issues: i) Food security status; ii) Socio-cultural, economic factors and policy related challenges affecting food security; and iii) the way households with PWDs cope with food shortage.

\section{Conceptual Clarity and Overview of Empirical Literature Poverty and Disability}

Poverty is inextricably linked to disability as both a cause and a consequence (Elwan 1999). As a cause, conditions of poverty add to the risk of disability. A World Bank (2001) study on poverty and disability has revealed that poor households do not have sufficient food, basic sanitation, and access to preventive health care. Hence, the poor segment of the society live in lower quality housing, and some work in more dangerous jobs. Malnutrition arising from poverty can induce disability, as well as increasing susceptibility to other disabling diseases. 
Undernourished mothers have low-birth weight babies, who are more at risk of contracting debilitating diseases than healthy babies. Lack of effective and available health care can worsen the effects of disease, causing a remedial condition to become a permanent disability (Elwan 1999).

\section{Types of Disabilities}

Disability by type involves motor disorders, physical disabilities, visual impairment, hearing impairment, mental retardation, speech and language disorders, behavioral problems, and multiple disabilities. In the case of Ethiopia, it is quite common that the community keeps most of the PWDs at their home secretly because of social stigmatization (EFPD 2001). This is partly due to a lack of information on the real causes of disabilities and the stigma attached to disability. Some people believe that the causes of disabilities are punishment inflicted by God in relation to their families' sin or disobedience to God (EFPD 2001).

\section{Models on Disability and the way they Shape the Global Responses}

Literature on disabilities identify four types of models namely charity, medical, social and citizenship models.

\section{Charity Model}

The charity model was the principal paradigm up to World War II, and is the philanthropic and charitable approach to disability that provided medical treatment, community aid, and safekeeping for those described as being "less fortunate" and "defective" (Edmonds 2005:18). This model looks disability as a personal tragedy with PWDs being objects of pity and referred to as "crippled," "crazy" or "idiot". It also promoted the perception that people with disabilities do not have the capacity to become equal members of society. Therefore, many PWDs were institutionalized for their own good (Barnes and Mercer 2003).

\section{Medical Model}

The medical model emerged in post World War II as a result of significant progress and advancement in the health sciences, technology, and pharmaceutical industry (Edmonds 2005:19). This created unprecedented improvements in the capacity of society to prevent the causes of impairment and improve the functional independence of people with impairments. The services were provided within a paradigm that perceived people with impairments ("disabilities") as "sick". While these people had the right to receive rehabilitation and medical services, it was the professionals who had the responsibility to decide what was best for the "sick" (Gadacz 1994). 


\section{Social Model}

The social model marked the 1970s and 1980s. It emerged as a result of a political movement led by PWDs to destabilize and deconstruct the medical model of disability (Edmonds 2005:20). It was a response to the medicalization of disability and its profound negative effects on the self-identity of many PWDs, and the negative attitudes created as a result of the charity and medical models. The aim was to create positive attitudes about PWDs by PWDs, their families, and especially society as a whole. This was to be achieved by creating a better understanding of the rights of PWDs and the imperative to overcome the economic, social, and environmental barriers that affect the ability of PWDs to participate and engage in community life like other citizens (Hans and Patri 2003).

Advocates of the social model convincingly argued that the problem to be addressed is neither biological nor medical and that it is not the individual but the social context that is disabling. The social model clearly articulates the power of and necessity for consumer participation in decision making to facilitate good and sound governance through inclusion of people with disabilities in policy making (DeJong 1993).

\section{Citizenship Model}

The period of the 1990s to the present represents a further re-conceptualization of disability and development into the citizenship model (CAILC 1993). It identified the need to bridge the dichotomy of the medical and social models by using an integrated development approach (WHO 2001). In this model, however, empowerment has a much broader definition and scope than in the medical and social models. Accordingly, the citizenship model represents an international development paradigm in which PWDs deserve and aspire to have the same opportunities as other citizens of their community. The current research is mainly informed by social and citizenship perspectives on disability, although the ideas of charity and medical models were not fully ignored.

\section{Food Security and Household Coping Mechanisms}

Food security "exists when all people, at all times, have physical and economic access to sufficient, safe, and nutritious food to meet their dietary needs and food preferences for an active and healthy life" (FAO 2007). Conversely, food insecurity is a situation in which the individuals of a society have neither the physical nor the economic access to the nourishment they need. Also, it is defined as a limited or uncertain availability of nutritionally adequate and safe foods or limited or uncertain ability to acquire acceptable foods in socially acceptable ways. Food security includes at a minimum: (1) the ready availability of nutritionally adequate and safe foods; and (2) an assured ability to acquire acceptable foods in socially acceptable ways (e.g., without resorting to emergency food supplies, 
scavenging, stealing, or other coping strategies). Food security conceptualization and indicators are commonly related to four key pillars namely availability, access, utilization and stability. Availability refers to sufficient food quantities of appropriate quality, supplied through domestic production or imports (including food aid). Access is about adequate resources (entitlements) to acquire appropriate foods for a nutritious diet. By utilization we mean the utilization of food through adequate diet, clean water, sanitation, and health care, to reach a state of nutritional well-being in which all physiological needs are met. Stability entails the regularity of access to adequate food at all times, independent of shocks or cyclical patterns (Degefa and Tesfaye 2009; Anderson and Elisabeth 2015).

Households adopt various behavioral and material responses to cope with adverse situations of food shortage crises (Alem 1999; Yared 2001; Meskerem and Degefa 2015). Different households within a community stand at different points along the continuum and their response to threat varies depending on their resource endowment, access to community support and access to public intervention (Webb \& Braun 1994).

Maxwell (1996: 74) categorizes household responses to food insecurity into two: coping strategies and adaptive strategies. Coping strategies are responses made by households to improve the declining situation of households food security, while adaptive strategies involve, a permanent change in the mix of ways in which food is required, irrespective of the year in question and it refer to longterm adjustment. The most commonly practiced coping strategies during abnormal season include short-term dietary change, changing intra household food distribution like skipping adults to feed children, limiting size and frequency of food, borrowing and gifts from relative and friends, mutual support mechanism, selling of livestock and fire wood, cash for work and relief assistance, etc (Maxwell 1996; Degefa 2005; Meskerem \& Degefa 2015).

\section{Description of the Study Area and Methods Hawassa City Setup}

Hawassa is the capital city of Southern Nations, Nationalities and Peoples Regional State (SNNPRS), Ethiopia. The population of Hawassa increased from 41,138 in 1987 to 455,658 in 2017, of which 228,044 are Male and 227,614 are female (CSA 2013). The Hawassa City Administration covers an area of 16, 062 hectares and is sub-divided into eight Sub-Cities and 32 Kebeles (Figure 1). Selassie, the study Kebele falls in Addis Ketema Sub-City. There are 1607 people with various types of disabilities (980 male and 627 female) in Hawassa city (CSA 2014). 


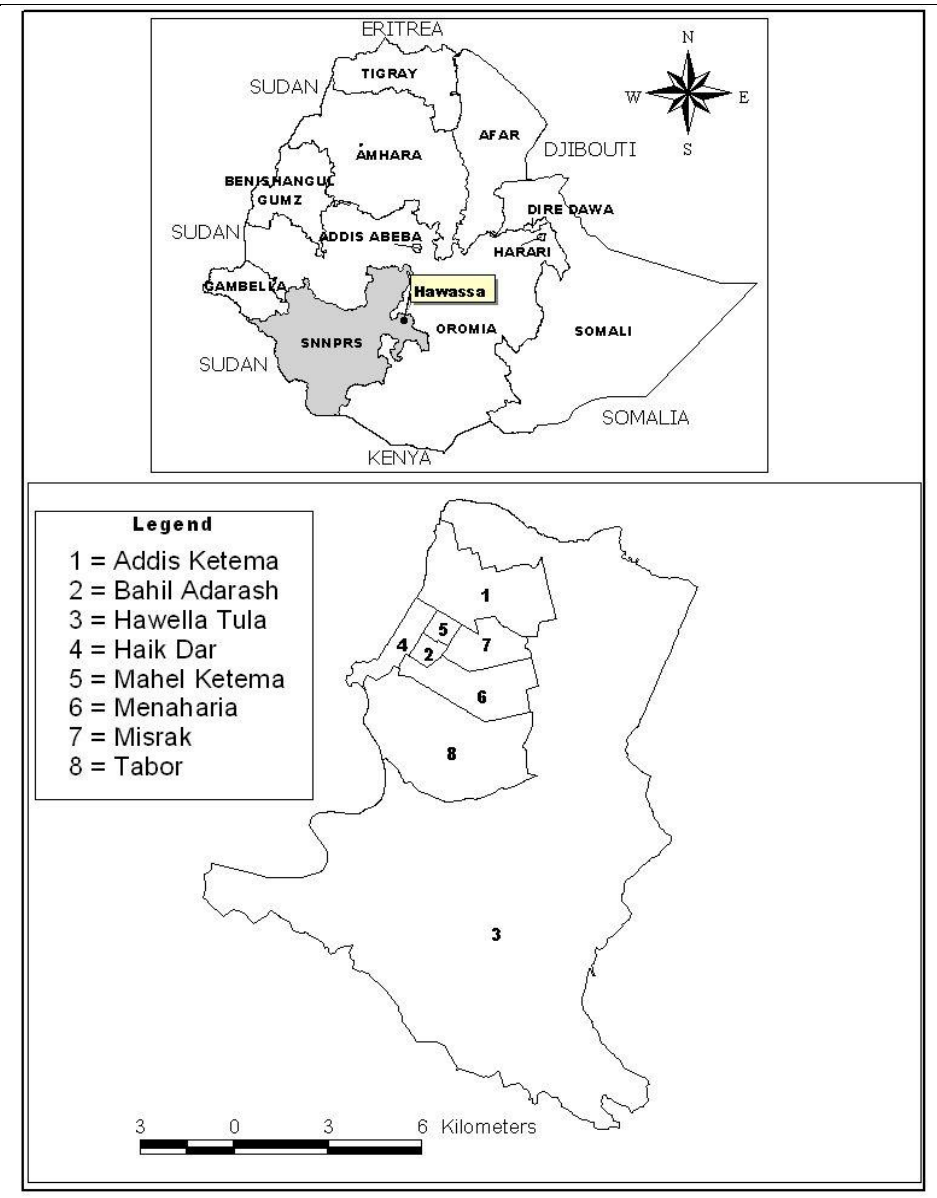

Figure 1. Location of Hawassa City and its Sub-cities

\section{Study Site Selection and Sampling}

Hawassa city is purposively picked as a study area on two grounds. The first reason is the preliminary visit paid to the study site by the researchers that allowed us to observe that the place is suitable to examine the nexus between disability and food security. It was observed that the livelihoods situation of some households with PWDs were in bad shape. The second justification is the researchers' familiarity with the area.

The study relied on the mix of qualitative and quantitative approaches to generate the first-hand data. The participatory qualitative methods employed in the research include Focus Group Discussion (FGD), Key Informant Interview (KII), in-depth interview with some case studies on PWDs, and observations. Purposive 
sampling was considered for all qualitative methods since the informants were selected on the basis of their social positions, roles in the community, and the knowledge of the community.

A questionnaire-based household survey was conducted in Selassie Kebele of Hawassa city. Selassie kebele was chosen since it is the host for the largest number of households with PWDs according to the information from Cheshire Service Ethiopia (CSE) at Hawassa. The sampling of households and PWDs involved the following steps. First, we looked for the total number of households that inhabit in this specific kebele, which was found to be 590. Second, on the basis of the records of CSE, households that own a person with any type of disabilities were identified. Accordingly, 100 households were found to have PWDs who have different types of disabilities in one or among more members of the households. Third, households were stratified according to the types of disabilities of their member. Out of the 100 households, all people with visual (18), and speech and/or hearing types of disabilities (10) were taken as a samples. 52 households with physical types of disabilities were randomly sampled out of 72 households with these characteristics. Thus the total sample of households with PWDs becomes 80. By chance each sampled household owns single individual with disabilities. In addition, another 16 households who have no PWD were chosen as control group for comparing households' food security status on the basis of the standard tool of Coping Strategy Index (CSI). It is important to underline that none of the data in this article was attached to actual name of individuals being interviewed or took part in group discussion.

\section{Data Analysis Approaches}

The generated qualitative data were carefully transcribed, thematically classified, described and analyzed. The narratives were presented via direct quotes and in the form of case boxes. The survey data was analyzed on the basis of various descriptive statistics and cross-tabulation of indicators of households and PWDs characteristics vis-à-vis indicators of food security. In order to assess household food security status, household Coping Strategy Index (CSI) was employed. Factors that affected the food security of households with PWDs were documented largely through qualitative approaches including narratives and case boxes.

Coping Strategy Index (CSI): - The Coping Strategies Index (CSI) is an indicator of household food security that is relatively simple and quick to use, straightforward to understand, and correlates well with more complex measures of food security (Maxwell et al. 2003). A series of questions about how households manage to cope with a shortfall in food for consumption results in a simple numeric score (Devereux 2001). Changes in the index provide a rapid indication of whether food 
insecurity is getting worse, or the situation is improving - a higher score indicates a greater level of coping, and thus increased food insecurity (Caldwell 2008). The computation and analysis of CSI involves five interrelated steps. These are:

- Step 1 Coping Behaviors: Getting the right list for the location;

- Step 2 Frequency: Counting the frequency of strategies;

- Step 3 Severity: Categorizing and weighing the strategies;

- Step 4 Scoring: Combining frequency and severity for analysis; and

- Step 5 Analysis: Correlating CSI with other information.

Data is collected on the number of days in the last seven days a household used a specific coping strategy due to a shortage of food. A seven day recall period is used to make the CSI as precise as possible. It allows to capture information on as many coping strategies as possible, especially the most severe (CARE/WFP 2008).

\section{Results and Discussion}

\section{Characteristics of Respondents}

The majority of respondents $(46.2 \%)$ were in the age ranges of 37-47 years followed by those whose age falls into the range of 48-58. About $60 \%$ of all heads of households with PWD studied were male and the remaining $40 \%$ were female.

The unemployment of disabled people is due to lack of education and training (Beresford 1996). We found out $56.3 \%$ of PWDs are unable to read and write while $22.5 \%$ of the respondents can read and write (Table 1). Those people who have secondary education and above constituted only $7.5 \%$ of all respondents.

Of the 45 individuals who were unable to read and write, $66.7 \%$ were people with physical impairment, $20.0 \%$ were people with visual impairment, and the rest $13.3 \%$ had speech and/or hearing impairment. The total number of respondents who could attain the level of reading and writing were 18 . A significant proportion of it $(61.1 \%)$ were found out to be persons with physical type of disabilities, 22.5 $\%$ of the respondents who could read and write were individuals with visual disability, and the rest had speech and/or hearing impairment. 
Fiseha Endale and Degefa Tolossa

\begin{tabular}{|c|c|c|c|c|c|c|c|c|}
\hline \multirow{3}{*}{$\begin{array}{l}\text { Educational } \\
\text { status }\end{array}$} & \multicolumn{8}{|c|}{ Type of Disability } \\
\hline & \multicolumn{2}{|c|}{ Physical } & \multicolumn{2}{|c|}{ Visual } & \multicolumn{2}{|c|}{$\begin{array}{c}\text { Speech } \\
\text { and/or } \\
\text { Hearing } \\
\end{array}$} & \multicolumn{2}{|c|}{ Total } \\
\hline & $\mathrm{N}$ & $\%$ & $\mathrm{~N}$ & $\%$ & $\mathrm{~N}$ & $\%$ & $\mathrm{~N}$ & $\%$ \\
\hline $\begin{array}{c}\text { Unable to Read } \\
\text { and Write }\end{array}$ & 30 & 66.7 & 9 & 20 & 6 & 13.3 & 45 & 56.2 \\
\hline Read and Write & 11 & 61.1 & 4 & 22.2 & 3 & 16.7 & 18 & 22.5 \\
\hline $\begin{array}{c}\text { Church/Koran } \\
\text { School }\end{array}$ & 3 & 100 & 0 & 0 & 0 & 0 & 3 & 3.8 \\
\hline Primary School & 5 & 62.5 & 2 & 25.0 & 1 & 12.5 & 8 & 10 \\
\hline $\begin{array}{c}\text { Secondary } \\
\text { School }\end{array}$ & 3 & 75.0 & 1 & 25.0 & 0 & 0 & 4 & 5 \\
\hline $\begin{array}{l}\text { Higher } \\
\text { Education }\end{array}$ & 0 & 0 & 2 & 100 & 0 & 0 & 2 & 2.5 \\
\hline Total & 52 & 65.0 & 18 & 22.5 & 10 & 12.5 & 80 & 100 \\
\hline
\end{tabular}

Source: Field Survey 2015

\section{Types of Disabilities and Its Causes}

People with three forms of disabilities, i.e., physical disabilities (65\%), visual $(22.5 \%)$, and speech and/or hearing types of disabilities $(12.5 \%)$ were identified in the community under study. Accidents (for $48.7 \%$ ), since birth (for $31.2 \%$ ) and illness (for $12.5 \%$ ) were the causes of disabilities.

\section{Livelihood Activities and Strategies}

Selassie kebele is within urban setting and thus most households engage in nonfarm activities (Table 2). In fact, some $57.5 \%$ of the respondent PWDs were unemployed. Sale of Baltina products (home-made food staffs) mainly by female household heads and female members of the family constitutes the largest share (13.7\%) followed by those who worked as a daily laborer in various private companies and at individual residential houses, which accounted for $11.2 \%$.

Out of 46 respondents who were found out to be unemployed, $93.5 \%$ were persons with physical disability, the rest $6.5 \%$ were persons with visual impairment. Sale of Baltina products was found out to be practiced mainly by 
persons with speech and/or hearing impairment ( $72.7 \%, 8$ out of 11 respondents); the remaining $27.3 \%$ were persons with visual impairment. Daily Labor was also found out to be one of the typical types of work in which PWDs engaged. Nine persons with disability worked as daily laborers. ${ }^{3}$ All of the respondents were with visual impairment. These respondents were engaged in various supportive activities as daily laborers in CSE compound.

Table 2. Disability Types by Livelihood activities

\begin{tabular}{|c|c|c|c|c|c|c|c|c|c|c|c|c|c|c|c|c|}
\hline \multirow{3}{*}{$\begin{array}{l}\text { Type of } \\
\text { disability }\end{array}$} & \multicolumn{16}{|c|}{ Livelihood activity } \\
\hline & \multicolumn{2}{|c|}{ 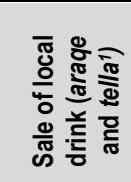 } & \multicolumn{2}{|c|}{ 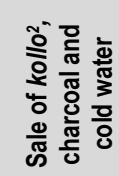 } & \multicolumn{2}{|c|}{ 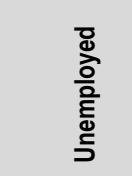 } & \multicolumn{2}{|c|}{ 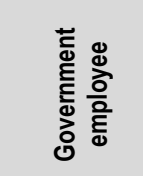 } & \multicolumn{2}{|c|}{ 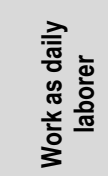 } & \multicolumn{2}{|c|}{ 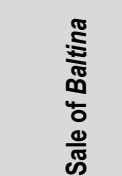 } & \multicolumn{2}{|c|}{ 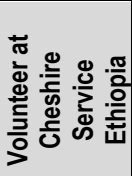 } & \multicolumn{2}{|c|}{ 呓 } \\
\hline & $\mathrm{N}$ & $\%$ & $\mathrm{~N}$ & $\%$ & $\mathrm{~N}$ & $\%$ & 1 & $\%$ & $\mathrm{~N}$ & $\%$ & $\mathrm{~N}$ & $\%$ & $\mathrm{~N}$ & $\%$ & $\mathrm{~N}$ & $\%$ \\
\hline Physical & 4 & 100 & 5 & 10 & 43 & 93.5 & c & 0 & 0 & 0 & 0 & 0 & 0 & 0 & 52 & 65 \\
\hline Visual & 0 & 0 & 0 & 0 & 3 & 6.5 & 3 & 100 & 9 & 100 & 3 & 27.3 & 0 & 0 & 18 & 22.5 \\
\hline $\begin{array}{l}\text { Speech } \\
\text { and } \\
\text { hearing }\end{array}$ & 0 & 0 & 0 & 0 & 0 & 0 & c & 0 & 0 & 0 & 8 & 72.7 & 2 & 100 & 10 & 12.5 \\
\hline Total & 4 & 100 & 5 & 10 & 46 & 100 & 3 & 100 & 9 & 100 & 11 & 100 & 2 & 100 & 80 & 100 \\
\hline
\end{tabular}

Source: Field survey, 2015

Note: 1. Araqe and tella are local beverages made of barley, maize and millet.

2. Kollo - roasted barley, wheat or beans

\section{Food Security Status of Households}

Quite a lot of studies are focused on measurement of households' food security, and these days there is a shift from objective measurement of food intake to people's own perceptions of their food supply situation. This study relied on households Coping Strategy Index (CSI), which gave the study participants the opportunity to express their own perceptions.

\section{Food Self-sufficiency}

According to Degefa (2005), self-sufficiency in the context of peasants who are leading subsistence way of life entails whether the crops and livestock they produce at home cover their annual food consumption requirements or not.

\footnotetext{
${ }^{3}$ It includes Cotton weaving in private business firms and all round child education and supportive activities at the compound of Cheshire Service Ethiopia on a daily wage basis. They are helped by other people most of the time.
} 
Participants of the FGD which included all types of PWDs characterized non-self sufficient household as 'one who fails to feed the family at least twice a day'. Based on this contextual definition, households were asked about their perception of their households' whether they were self-sufficient or not. Some $96.3 \%$ of the respondents reported that income generated through different activities did not cover their annual food consumption requirements.

The survey result generally entails the less availability of food through income generated by non-farm activities. For more than $86 \%$ of the respondents, the maximum duration that their monthly income covers was one week to ten days. The rest $8.8 \%$ and $5 \%$ said that their average monthly income sustains the household to the maximum duration of two weeks and three weeks, respectively. Hence, most households live under chronic food shortage.

\section{Household Food Security}

The concept of food-security differs from self-sufficiency in that the former encompass a number of issues such as 'access', 'utilization', 'stability' and 'availability' while the latter mostly deals with food availability dimension alone (Degefa 2005). In light of this, households were asked to differentiate their household level of food security as food secure, seasonally food insecure, and chronically food insecure and the result is summarized in Table 3.

Table 3. Self-reported food security status by type of disability

\begin{tabular}{|l|c|c|c|c|c|c|c|c|}
\hline \multirow{2}{*}{$\begin{array}{l}\text { Food Security } \\
\text { Status }\end{array}$} & \multicolumn{9}{|c|}{ Type of Disability } \\
\cline { 2 - 11 } & \multicolumn{2}{|l|}{ Physical } & \multicolumn{1}{l|}{$\begin{array}{l}\text { Visual } \\
\text { hearing }\end{array}$} & \multicolumn{2}{l|}{} \\
\hline & $\mathrm{N}$ & $\%$ & $\mathrm{~N}$ & $\%$ & $\mathrm{~N}$ & $\%$ & $\mathrm{~N}$ & $\%$ \\
\hline Food Secure & 0 & 0 & 2 & 50.0 & 2 & 50.0 & 4 & 5.0 \\
\hline $\begin{array}{l}\text { Seasonally Food } \\
\text { Insecure }\end{array}$ & 3 & 50.0 & 2 & 33.3 & 1 & 16.7 & 6 & 7.5 \\
\hline $\begin{array}{l}\text { Chronically Food } \\
\text { Insecure }\end{array}$ & 49 & 70.0 & 14 & 20.0 & 7 & 10.0 & 70 & 87.5 \\
\hline Total & 52 & 65.0 & 18 & 23.0 & 10 & 12.5 & 80 & 100.0 \\
\hline
\end{tabular}

Source: Field Survey, 2015

The survey result shows that the overwhelming majority $(87.5 \%)$ to be chronically food insecure. Some $5 \%$ of the participants reported being food secure. No one among persons with physical disability was identified to be food secure. Food secure persons with disability were equally distributed between visually impaired and speech and/or hearing impaired. While $50.0 \%$ (3 of 6) of persons with 
physical disability were categorized under seasonally food insecure, $33.3 \%$ and $16.7 \%$ were found out to be visually and speech and/or hearing impaired, respectively. The majority ( $70 \%$ ) of chronically food insecure respondents were persons with physical disabilities. This would clearly imply that physical disability hinders engagement in productive livelihood activities that eventually requires being physically fit.

\section{Frequency of Meals}

The study result on the average frequency of food intake during the seven days prior to data collection showed, $78.8 \%$ of the respondents had on average food intake once a day. It can be understood that regardless of the type of foods they consume those who accounted for one meal per day were undernourished. The rest $18.8 \%$ and $2.5 \%$ reported average intake of two and three times a day, respectively.

\section{Change and Continuity in the Type of Meal}

The type of meal that is consumed in a given household largely depends on the economic status and cultural preferences of the people. The change and continuity in the type of meals that people consume at home, to some extent, tell the food security status of households. What people consume under normal situation may differ from times of livelihood economic crises (Degefa 2005).

An in-depth interview with unemployed, 47 years old, physically disabled female widowed household head, indicated that injera as she said which was made with a mix of teff and maize with shirro wott (kind of stew), was what many households consume at normal times. Besides, in very few relatively well to do families, injera made from teff alone with different kinds of wot (kind of stew) is served. During seasons of food shortage poor households usually shift to cheaper and easily prepared food items such as kita and genfo (porridge made from maize), nifro and Kolo made mainly from maize sometimes mixed with other cereals and pulses. Some $91 \%$ of households reported that they have shifted towards less preferred and the cheapest food staffs over the last periods.

\section{Food Security Status as per the Result from Coping Strategy Index (CSI)}

On the basis of CSI, we compared food security status of four groups namely households with no PWDs, households with physical type of disabilities, households with visual type of disabilities, and households with speech and/or hearing type of disabilities. The CSI score for the households with no disabled family members who inhabit in the same kebele did not show the most severe sign of food insecurity in any of the indicators except the coping strategy of "reducing number of meals eaten in a day" (Annex I). The raw score was even zero in three out of eleven of the food security indicators. It implies that the respondents from 
this category did not practice any of the extreme coping mechanisms against food insecurity.

Selassie Kebele community members with physical type of disability used all their last options to cope with food insecurity problem facing them (Annex II). They get relief food/money, beg, reduce number of meals and skip food. Their CSI score implied severe level of food insecurity in contrast to their community inhabitants with no members of PWDs.

Households with visual PWDs were found out to be more food secured than those with physical type of disability (Annex III). In fact, their food insecurity level is worse than households with non-disabled members.

Community members with PWDs of speech and hearing were found out to be better than respondents with physical and visual PWDs in terms of their level of food security. And yet they were less food secure than the non-disabled households category of respondents (Annex IV).

The findings clearly reveal that households with physical, visual, speech and/or hearing disabilities were less food secured than the household with no PWDs. The household Coping Strategy Index score for the latter was 29, by far lower than the other three categories of households with three types of disabilities under investigation. Among households with no PWDS, none of the most severe coping behaviors are noted.

The household with physical type of disability were affected by more severe food insecurity than the other categories. The Coping Strategy Index score of PWDs of physical type, visual and speech and/or hearing were 85, 71 and 56, respectively.

\section{Causes of Food Insecurity among People with Disabilities}

The interview held with the Cheshire Service Ethiopia (CSE) mainstreaming sector head revealed that the main challenges PWDs face was attitudinal. The challenges are related to personal, family, school, society, and career life. In the day-to-day life of PWDs any one or more of the attitudinal challenges drag them from thriving. Shortage of assistive devices is the other challenge. For instance, for the whole PWDs in the Southern region of Ethiopia, assistive devices were produced only in three places, i.e., at Cheshire Hawassa, and two other government centers. The production capacity of the centers is limited because the raw materials are not available in country and thus are imported from abroad.

The other barrier is a physical one. Most buildings in the city of Hawassa, for instance, are not accessible to PWDs. The situation is painfully worse in the rest of the towns in the region. An adapted toilet is also one of the facilities that PWDs is missing dearly all over south Ethiopia. The fact that the agenda of PWDs has not been mainstreamed using public networks yet, coupled with accessibility and 
employability problems remain unresolved and hence improving the food security status of PWD becomes miles away.

The study participants prioritized the major factors that adversely affect the food security and livelihood status at household level as socio-cultural factors $(42.5 \%)$, policy related challenges (32.5\%), and economic constraints $(25 \%)$.

\section{Economic Factors}

\section{Lack of Start-up Capital}

Some activities such as petty trading require a sizable amount of cash to start the business. However, due to shortage of financial capital among most poor households many households are unable to secure and improve their livelihood activities. Credit Associations could be an important source of cash for households. However, according to one of the FGD participants, although government financial credit providing institutions such as Omo Micro Finance Credit Institution and Sidama Micro Finance Credit Institution are there to provide the service, PWDs lack access to credit as they are not included in any self-help groups, and other credit facilities are unavailable in the area around the study Kebele. Moreover, it was found out that stakeholder's negative feelings about the ability and creditworthiness of PWDs deprived them from accessing any credit.

Interview with an official of CSE revealed that the socio-economic environment is the most influential challenge. If we take Micro Financial Institutes (MFIs) who lend for people with low income, they do not want to lend any money to PWDs. MFIs would not believe PWDs to be able to work and pay back the loan. The policy for inclusive development is there but the lower level implementers of the policy were not knowledgeable and committed for that.

\section{Lack of Access to Credit}

More than $58 \%$ of the participants in this study responded that they do not have any type of credit association that would provide service to PWDs in and around the community studied. One adult man with speech and/or hearing type of disability who participated in an interview indicated that, as he believed, the rationale behind their being discriminated in getting the credit service was that the service providers believe that PWDs do not deserve to access credit since they will not manage to pay back as the day approaches. About $41 \%$ of the participants replied about the availability of access to credit but they enormously stressed that they faced a number of obstacles during undertaking the processes. These include intentionally delaying, queering different unwanted criteria which never exist in the rules and regulations from the side of the workers in the institutions. Above all, PWDs were highly embarrassed with various body and facial expressions that have damaged them psychologically. 


\section{Lack of Supporting /Assistive Devices}

The survey result shows that some $60 \%$ of the investigated individuals do not use assistive devices. The official of CSE said that Arbaminch Rehabilitation Center (ARC) is the only institution to produce the assistive devices for all PWDs in southern Ethiopia. The same informant underlined that the center has no sufficient capacity for distributing the product for the beneficiaries who use it for the very first time, and for those who want to replace the old ones. In addition, the freely available assistive devices also were not accessible for PWDs in the study Kebele.

One of the participants said that:

"I badly need a hearing aid. Those who can travel outside can get it free but I cannot go so that it becomes so challenging to me to communicate or lead my own life independently. Hence I am always seeking the support of family, relative or friends".

\section{Limited Employment Opportunities}

The woman informant with physical type of disability stated that PWDs have a slim chance of getting job as they cannot work in physical labor-oriented activities that require mobility. The opportunity for women with various forms of disability is further reduced as men are more preferred for some works. Furthermore, lack of opportunities and access to become involved in any other labor work forced women with disabilities to be restricted to household activities. Some $40 \%$ of the respondents are unemployed and thus have no permanent monthly income. Another 37 and $14 \%$ had a monthly salary of less than 500 ETB, and between 500 and $1000 \mathrm{ETB}$, respectively. A negligible proportion of the sample (8.7\%) worked in jobs that earn them greater than 1000 ETB per month.

Out of 52 respondents with physical disability, $(51.9 \%)$ did not have monthly income at all, and another (40.7\%) reported that they earn less than Birr 500 per month. $55.6 \%$ of respondents with visual disability had no monthly income, or did earn less than Birr 500 a month. Although all sample respondents with speech and/or hearing impairment responded to have some sort of monthly income, $80 \%$ of them earned less than Birr 500 (40\%) and between Birr 500 and Birr 1000 (40 $\%)$ (Table 4). 
Table 4. Type of Disability by Monthly Income

\begin{tabular}{|c|c|c|c|c|c|c|c|c|c|c|c|c|}
\hline \multirow{3}{*}{$\begin{array}{l}\text { Type } \\
\text { of } \\
\text { disability }\end{array}$} & \multicolumn{12}{|c|}{ Monthly average income (ETB) } \\
\hline & \multicolumn{2}{|c|}{$\begin{array}{l}\text { No } \\
\text { monthly } \\
\text { income }\end{array}$} & \multicolumn{2}{|c|}{ less than 500} & \multicolumn{2}{|c|}{$500-1000$} & \multicolumn{2}{|c|}{$\begin{array}{l}1000- \\
2000\end{array}$} & \multicolumn{2}{|c|}{$\begin{array}{l}\text { Greater } \\
\text { than } \\
2000\end{array}$} & \multicolumn{2}{|c|}{ Total } \\
\hline & $\mathbf{N}$ & $\%$ & $\mathbf{N}$ & $\%$ & $\mathbf{N}$ & $\%$ & $\mathbf{N}$ & $\%$ & $\mathbf{N}$ & $\%$ & $\mathrm{~N}$ & $\%$ \\
\hline Physical & 27 & 51.9 & 21 & 40.4 & 3 & 5.8 & 1 & 1.9 & 0 & 0 & 52 & 65 \\
\hline Visual & 5 & 27.8 & 5 & 27.8 & 4 & 22.0 & 3 & 16.7 & 1 & 5.6 & 18 & 22.5 \\
\hline $\begin{array}{l}\text { Speech } \\
\text { and/or } \\
\text { Hearing }\end{array}$ & 0 & 0 & 4 & 40.0 & 4 & 40.0 & 1 & 10.0 & 1 & 10 & 10 & 12.5 \\
\hline Total & 32 & 40.0 & 30 & 37.5 & 11 & 14 & 5 & 6.25 & 2 & 2.5 & 80 & 100 \\
\hline
\end{tabular}

Source: Field Survey, 2015

\section{Lack of Education, Training and Self-employment Facilities}

Feasible self-employment options in the Selassie Kebele and around were hindered due to non-availability of necessary resources. The Male Focus Group (MFG) participants with physical type of disability suggested trades like poultry, stationery, and tailoring and grocery shops as the possible opportunities. The Female Focus Group participants recommended trading dry foods, cotton and Baltina production can be suitable for women with disabilities. Both groups pointed out lack of education, training and credit facilities, social pressure, unavailability of raw materials and limited marketing opportunities as the major roadblocks for initiating self-employment activities. 


\section{Box 1}

Case Story of a Visually Impaired Woman who Reflects on Economic Challenge she Faced while Trying to Access and Contact Saving and Credit Institutions

Almaz Girma, 28, is an unemployed visually impaired woman. She has been dreaming of starting a small business as she couldn't find a job after graduating from a public university four years ago. She says "I could understand that finding a job for any new graduate is tough, but what I could not understand was why employers doubted me without even testing my skills only because I was blind". She thought that it was time for her to join a cooperative with her friends who faced similar challenge of finding a job due to their disabilities. Having fulfilled all the necessary criteria, the team went to a Micro Financing Institute (MFI) to get a loan for a start up, but it was in vein. They are not able to get the loan that every cooperative has been getting so easily. They tried another MFI, nobody would even talk to them. They did not want to fail seemingly on their last road to independence; they kept on looking for any MFI or even anybody who could lend them little money to start up the very small business.

It was not unprecedented at all that they could not get a loan for their cooperative which constituted two members that have limited mobility, two have vision impairment, one has speech impairment and another has hearing impairment. The MFIs would not believe PWDs would pay them back their money. Almaz sadly says, "Nobody thinks a person with disability could do something worthwhile; everybody seems to sympathize for our disabilities, but they do not want to give us any chance to prove our abilities. They could have given us a penny when we end up on the street and beg." All of the six members of the cooperative are dependent on their families; they could not help themselves even possessing the right schooling and skill sets.

\section{Socio-cultural Factors}

Social Stigma and Lack of Awareness among Family

Family members' lack of knowhow, and its impact on PWDs livelihoods, was reported during individual interviews. For example, rehabilitation centers like CSE have rare provisions of free treatment plus some periodic aids and appliances. However, due to family members' limited knowledge regarding free facilities, many of PWD are yet to avail them. According to the step-mother of 18 years old woman with visual impairment, Butu, who revealed her thought on the issue: 
"As a woman, most of the time, I am restricted to my house. I am not able and allowed to go out frequently. Therefore, I do not have any idea about the existing facilities for people with disabilities".

Furthermore, for fear of losing family status and to protect the child from exploitation, parents prevent disabled members from going out for education or rare employment opportunity. For instance, CSE provides services such as rehabilitation, medical, psychosocial, educational and vocational trainings for PWDs. However, very few disabled people in the village have availed themselves to these facilities. Family members feel that sending disabled people to a charitable organization will affect their social status. Other people in the study Kebele feel that family members could not feed a disabled person and sent him/her to a charity home. The situation is acute for disabled women. Butu's step-mother shared that:
"We are concerned about our status. If our daughter goes out for work, people will say that her father cannot afford her food and clothing so he sent a disabled girl to work outside. We also fear that anything may go wrong with a young girl if she goes out."

Interview with the president of UAPD revealed that family as the first agent is the most important factor of all others. For example, he remembers a father who had wanted to die rather than his blind daughter would have gone to school. Therefore, it is parents who can decide more and first on the future of their disabled children. If parents do not help their child with disability (CWD) integrate with the larger community around, it affects the child negatively in the future.

\section{People with Disabilities Lack of Awareness}

PWDs' lack of awareness was observed during field work for this study. They do not know about where to go and whom to approach. It was further noticed that awareness levels of women with disabilities are much lower than their counterpart men. The FGD participants in women group mentioned that there are no existing facilities for PWDs and even if there were, they are not aware of them. Lack of awareness resulted in low levels of confidence and self-esteem, and reduced capacity of the PWD to engage in various livelihood activities. The survey result shows that majority of the respondents $(63 \%)$ did not have any information about organizations that provide services to PWDs.

\section{Powerlessness of Disabled People}

Most WFG participants expressed their limited knowhow and helplessness during discussion. They kept complete silence when requested to provide suggestions about how to improve their livelihoods. They felt lack of attention and support, though they repeatedly requested the Kebele Administration to organize outside 
help through cooperatives to improve their livelihoods status. This would reflect the low confidence and self-esteem of women with disabilities due to lack of knowhow, inaccessibility of services, socio-cultural pressures and extreme control of family members over their lives.

On other hand, the MFG participants provided some suggestions to improve their livelihoods. This included availability of work in nearby areas; assistance in accessing credit; technical guidance for feasibility of businesses and marketing; linkages with the stakeholders and access to assistive devices and treatment facilities. Nonetheless, they voiced their lack of knowledge, social and financial power to avail themselves of these facilities. This powerlessness and lack of livelihood options also leads to frustration in the lives of most PWDs.

\section{Case Story of a Physically Disabled Woman who Reflects Socio-cultural Challenges}

Konjit Weret, 33, is a physically disabled widow who lives with her three children aged between three and nine years old. Konjit was plagued by Polio since she was so small. Her husband, Kassa Gebre, died just before the birth of their youngest child, Tesfahun Kassa, three. The father was the sole bread earner of the family working as a daily laborer. Due to the explicit discrimination she faced from the community around, Konjit had not been able to work outside home.

Due to the bitter discrimination of the society she had hidden herself at home for many years. But when the family started to go hungry every day, Konjit had to look for what she could do. She started to knock every possible opportunities of work; she could not get any. The discrimination she knew a number of years ago has not gone anywhere away.

She says, "It has been three years now, we are dependent on worshipers charity for little money or food. I am worried everyday about putting something to eat in my children's mouth. When it rains or when one of us gets sick, we cannot go out for begging. In such cases we do not have any other choice but to stay hungry for many hours or, even days.

She made a shack from plastic to sleep on the street next to a church. Following Kassa's death the family is evicted from their last rent house because they had no money to pay. "When I was a child a local health officer told me that my disability happened because I did not take proper vaccination, said Konjit. She added, "But it breaks your heart when you hear people explicitly speak to each other that you are different and cursed." 
If Konjit was given the opportunity to help her family thrive, her children would not have been begging for food, rather they would have been going to school. They could have a roof above their head. Konjit would have also been contributing her part to the community.

\section{Policy Related Factors}

The interview held with the Kebele Disability Mainstreaming Task Owner and Food Security Desk experts revealed that the major challenges that affect people with studied forms of disabilities were policies and legislations since they were not easy to access. Information about services and benefits is not widely known and is difficult to avail because of bureaucratic lethargy and intransigence. Also he said that the nature of the policies are general and not considerate of the specific situation, unique ability and distinct need in which people with disabilities relied on within the given context in order to make it somewhat practical and easy to implement.

\section{Access to Existing Resources}

The research found out that administrative complications, assessment procedures, misperceived attitudes of service providers and lack of appropriate knowledge for the job are the major challenges for PWDs in accessing existing entitlements. This complicated and unclear administrative system delays the service delivery for the needy people.

\section{Political Influence and being not Heard}

There is a common feeling among all the PWDs in the Kebele that lack of political power has deprived them from accessing any kind of services. MFG participants said that there are some schemes for PWD from the Federal Government but all these are unfairly executed for the benefit of the needy people at local level. Those who have money and power can access all these. However, PWDs are denied access to any facilities as they do not possess either of them. The group cited the example of some households who have been benefiting since they have close relatives or friend who works around administration areas. This would clearly imply that local politics, administrative complications, and lack of knowhow of stakeholders deprive PWDs from accessing their sources of livelihoods in general, and attaining food security in particular.

\section{Household Coping Strategies to Food Shortage}

Food insecure households in the study area develop their own mechanism of coping strategies to household food shortage. Though there are minor variations among households, the response of most of the household is based on market, consumption and transfer based mechanism. Likewise, households were asked to 
identify their coping mechanism while they face food shortage. The responses indicate that eating less preferred and cheap foods, reducing the number of meals eaten, limiting the portion size at mealtimes, begging on the street, skipping adults to feed children, borrowing food, or relying on help from a friend or relative and sending household members to eat elsewhere as the ways they cope with food shortage. Hence, the main coping mechanisms adopted by household in the study areas are used to increase household food availability through purchasing, assistance from others and reducing household consumption. The survey result revealed that, among the coping mechanisms, limiting portion of size at meal times and eating less preferred and cheap foods are practiced by the largest proportion of households, which is $22.5 \%$ and $20 \%$, respectively. Interview with official of CSE indicated that some PWDs have to find some sorts of survival strategies, and this is usually begging around churches or mosques. The community also tends to see PWDs as a subject of charity. Cheshire Hawassa tries to bring up a handful of successful PWDs in order to boost their morale setup.

\section{Conclusions}

The overall food security status in Selassie Kebele presents a bleak picture. Most PWDs in the study area lack education and have inadequate income and lesser savings. PWDs lack control over any of the five forms of capital. They lack access to savings, credits and social security schemes. Inaccessible transport and communication, and non-availability of disability equipment, have reduced their physical capital. Moreover, deprivation from education, skills training and treatment facilities and lack in the physical ability to work limits the human capital of PWDs. They lack social capital due to their non-involvement in most community saving groups and other networks.

The majority of people with physical disabilities, vision, and speech and/or hearing types of disabilities were chronically food insecure. Persons with physical type of disability face severe food shortage than the other groups. Only less than $4 \%$ of sample respondents reported to be food self-sufficient. The main causes for the physical disabilities were found out to be accidents, while impairments starting from birth resulted in disabilities of some. More than half of the studied households were unemployed, and peoples with physical disabilities constituted the largest proportion of unemployed people. Working as a daily laborer and sale of Baltina products were the types of occupations in which most PWDs were engaged.

In the absence of any opportunities, PWDs in the study area depend upon their families and relatives for their livelihoods who are unemployed, and others rely on petty trading and daily labor for survival. However, dependence on the 
mercy and charity of family and the medical model of assessment for welfare has made PWDs helpless and victims.

Moreover, PWDs have fewer chances of initiating any self-employment schemes due to limited education, training, savings, credit and marketing facilities as well as the prevailing social pressures. The majority of the respondents were unable to read and write, and a sizable number can read and write. Individuals with physical disabilities constitute the largest proportion of those who are unable to read and write. Inaccessibility of assistive devices and transport prevent them from getting education. Furthermore, the education of persons with disability is a low priority for parents as there is less likelihood of them getting any employment. Most stakeholders' lack of appropriate knowhow about the ability and creditworthiness of sample respondents deprived them from accessing any credit and employment which enable them to lead a better life. One of the many challenges facing PWDs is the socio-cultural factors of which perception of people towards disability is highly discouraging. Policy and economic related factors also adversely affected the food security status of PWDs. Limiting portion at mealtimes, eating less preferred and cheap foods and begging on the street were the major coping mechanisms against food shortage.

A number of ways as to how to improve household food security situation of PWD in Selassie Kebele were forwarded. We believe that it is the responsibility of all actors: government, NGOs and the public to contribute their parts. Hence, the following are some of the suggested remarks to improve household food security situations of PWDs.

- Since lack of information is a major barrier to the progress of PWDs, it is essential to disseminate information to change unwanted and misperceived attitudes towards PWDs in the society. It is also necessary to ensure that PWDs and those who work with them know, and can take advantage of reservations in jobs, education and poverty alleviation programs.

- Programs such as urban safety net programs, food for work and cash for work should be put in place. Such intervention programs need to be disabilityoriented through understanding specific disability context and distinct abilities of PWDs.

- PWD themselves must be encouraged to participate and take leadership roles in influencing public opinion and policies. Such inclusive strategies rectify or reduce some challenges of PWDs with regard to attaining food security. It is important to reduce the unfair treatment of various segments of PWD through mainstreaming them into all development programs and agenda.

- Barrier-free access to all livelihood assets, credit, education, public buildings, spaces and transport services and related issues should receive special attention 
so as to enhance better standard of living and food security, as well as to augment the PWDs' to use their abilities.

- It is important to augment rehabilitation service centers in the study area in order to address many segments of the population with disabilities in non discriminatory and fair way. 


\section{References}

Alem, Abrha. 1999. "Food Security in South Wollo" in Aspen H. and Abdulhamid B. Kello, editors. Poverty and Resources in Ethiopia (Working Paper on Ethiopia Development No. 13, AAU-IDR and Norwegian University of Science and Technology). Department of Anthropology: Norway.

Anderson, S. and Elisabeth, F. 2015. USAID Office of Food for Peace Food Security Country Framework for Ethiopia FY 2016 - FY 2020. Washington, D.C.: Food Economy Group.

Barnes, C., and G. Mercer. 2003. Disability. Cambridge: Polity Press.

Beresford, A. (1996). Hearing Impairment and Language Disorder: Assessment and Intervention. Gaithersburg: An Aspen Publication, Inc.

Canadian Association of Independent Living Centers (1993). A Step toward Independent Living: How to Develop an Independent Living Resource Centre in your Community (Resource Guide). Ottawa.

CARE/WFP. 2008. The Coping Strategies Index: Field Method Manual. ( $2^{\text {nd }}$ ed.). Nairobi.

Caldwell, R. 2008. TANGO International. Guide for Measuring Food Access: The Coping Strategies Index Field Methods Manual (2 ${ }^{\text {nd }}$ ed.). Developed for Food and Nutrition Technical Assistance (FANTA).USA.

CSA (Central Statistical Agency). 2013. Population of Ethiopia for all Regions: At Wereda Level from 2014 to 2017. Addis Ababa.

CSA. 2014. Projected Population \& Housing Census of Ethiopia. Addis Ababa.

Dagnew, Eshete. 2002. Food security, sustainable agriculture and trade: Issues of concern for Lobbying and advocacy (a report by IDCoF). Addis Ababa.

Degefa, Tolossa. 2001. Causes of Seasonal Food Insecurity in Oromiya Zone of Amhara Region: Farmers' View. Norwegian University of Science and Technology: Department of Geography.

Degefa, Tolossa. 2002. Household Seasonal Food Insecurity: Causes (Social Science Research Report. No. 26). OSSREA.

Degefa, Tolossa. 2005. Rural Livelihoods, Poverty and Food Insecurity in Ethiopia: A Case Study at Erenssa and Garbi Communities in Oromiya Zone, Amhara National Regional State (Doctoral Theses).NTNU.

Degefa, Tolossa. 2010. "Some realities of the urban poor and their food security situations: a case study of Berta Gibi and Gemechu Safar in Addis Ababa city, Ethiopia." Environment and Urbanization. 22(1): 1-20.

Degefa, Tolossa and Tesfaye Tafesse. 2009. "Linkages between water supply and sanitation (WSS) and food security in four case study communities of East Hararghe Zone, Oromiya Region." Ethiopian Journal of Development Research. 31 (1): 63-92.

DeJong, G. 1993. "Health care reform and disability: affirming our commitment to community." Archives of Physical Medical Rehabilitation. 74: 1017-1024. 
Devereux, S. 2001. Social Protection for the Poor (IDS working paper 142). Brighten.

DFID. 2014. Disability Framework: Leaving No One Behind. DFID.

Edmonds, L. J. 2005. The Critical Dimensions of Disability and Development. Kingston: Queen's University- ICA CBR.

Edge, J. 2013, March 27. Put disability on the Food Security Agenda [online blog post]. Retrieved from https://www.theguardian.com/global-developmentprofessionals-network $/ 2013 / \mathrm{mar} / 27 / \mathrm{mdgs}$-food-security-disabilitydevelopment-agenda

Elwan, Ann. 1999. Poverty and Disability: A Survey of the Literature. Washington, DC: The World Bank.

Ethiopian Federation of Persons with Disabilities. 2000. Bright Hope. A Bilingual Bulletin (No. 4). Addis Ababa: Ethiopian Federation of Persons with Disabilities.

EFPD. 2001. Bright Hope. A Bilingual Bulletin (No. 5). Addis Ababa: Ethiopian Federation of Persons with Disabilities Ethiopia.

FAO. 2002. Land Tenure and Rural Development. Rome: FAO Land Tenure Studies.

FAO. 2007. World Food Summit: Five Year Later. Rome: FAO.

Gadacz, R.R. 1994. Re-Thinking Disability: New Structures, New Relationships. Edmonton, Alberta: University of Alberta Press. Retrieved from http://www.mwud.gov.et/web/hawassa/home

Hans, A., and A. Patri. 2003. Women, Disability and Identity. London: Sage Publications.

Japan International Cooperation Agency (JICA). (2002). Country Profile on Disability: Federal Democratic Republic of Ethiopia. JICA: Planning and Evaluation Department.

Maxwell, S. and Smith, M., (1992). "Household food security: A conceptual review." in Maxwell, S. \& Frankenberger T.R., editors. Household Food Security: Concepts, Indicators, Measurements (a Technical Review). Rome: UNICEF and IFAD.

Maxwell, D. 1996. Measuring Food Insecurity: the Frequency and Severity of Coping strategies. Food Policy. 21(3): 291-303.

Maxwell, D. 2003. The Coping Strategies Index: A Tool for Rapidly Measuring Food Security and the Impact of Food Aid Program in Emergencies. Trivoli: Eastern and Central Africa Regional Management Unit, CARE and Vulnerability Assessment and Mapping, World Food Programme.

Meskerem, Abi. 2011. Household Food Security Situation in Girar Jarso Woreda, North Shewa Zone of Oromiya National Regional State, Ethiopia (MA Thesis). Addis Ababa University. 
Meskerem, Abi and Degefa, Tolossa. 2015. Household Food Security Status and Its Determinants in Girar Jarso Woreda, North Shewa Zone of Oromia Region, Ethiopia. Journal of Sustainable Development in Africa.17 (7): 118137.

Reutlinger, S. 1987. Lessons Learned on Inclusion of People with Disability in the ICCO Gaibandha Food Security Project for Ultra Poor Women. Netherlands: LIGHT FOR THE WORLD.

Scoones, I. (1998). Sustainable Rural Livelihoods: A Framework for Analysis (Working paper No. 72). IDS.

She, P., \& Livermore. 2007. "Material hardship, poverty, and disability among working-age adults." Social Science Quarterly. 88(4): 970-989.

Tirussew, Tefera., Savollainan, H., Agdew, R.,and Daniel, D. 1995. Baseline Survey on Disabilities in Ethiopia. Addis Ababa: Commercial Printing Enterprise.

Tirussew, Tefera. 2000. Human Disabilities: Developmental, Educational and Psychosocial Implications. Addis Ababa University: Department of Educational Psychology.

UNCRPD. 2011. Journal of Farming and Food Security Hub, Put disability on the food security agenda from the global development professional's network. New York.

World Bank. 2001. World Development Report 2000/2001: Attacking Poverty. New York: Oxford University Press

World Food Program (WFP) Ethiopia (2009). Food Security and Vulnerability in Selected Towns of Oromiya Region. Vulnerability Assessment and Mapping (VAM). Addis Ababa, Ethiopia September 2009.

Webb, P. and Von Braun, J. 1994. Famine and Food Security in Ethiopia: Lesson for Africa. Chichester: John Wiley and Sons Ltd.

Werner, D. 2005. Disabled Village; A guide for community health workers, rehabilitation workers, and families. Palo Alto, CA: The Hesperian Foundation.

World Health Organization (2010). CBR Guidelines: Livelihoods Component. Geneva: WHO Library Cataloguing-in-Publication Data.

World Health Organization (2001). International Classification of Functioning, Disability and Health. Retrieved from: http//: www.who.ch/icf

World Health Organization (2011). International Classification of Functioning, Disability and Health. Retrieved from: http//: www.who.ch/icf.

Yared, Amare (2001). "Food Security and Sustainable Livelihoods in Ethiopia." Proceedings of the Symposiums of Forum for Social Studies, Addis Ababa: Forum for Social Studies. 


\section{Annex I: CSI Score of households with no PWDs (N=16)}

\begin{tabular}{|c|c|c|c|}
\hline $\begin{array}{l}\text { In the past seven days, If there have been times when } \\
\text { you did not have enough food or money to buy food, } \\
\text { how often has your household had to: }\end{array}$ & $\begin{array}{l}\text { Raw } \\
\text { score }\end{array}$ & $\begin{array}{l}\text { Severity } \\
\text { weight }\end{array}$ & $\begin{array}{l}\text { Weighted score } \\
= \\
\text { Frequency*wei } \\
\text { ght }\end{array}$ \\
\hline $\begin{array}{l}\text { A. Rely on less preferred and less expensive } \\
\text { foods? }\end{array}$ & 2 & 1 & 2 \\
\hline $\begin{array}{l}\text { B. Borrow food, or rely on help from a friend or } \\
\text { relative? }\end{array}$ & 2 & 2 & 4 \\
\hline C. Purchase food on credit? & 1 & 2 & 2 \\
\hline D. Send household members to eat elsewhere? & 1 & 2 & 2 \\
\hline E. Begging? & 0 & 4 & 0 \\
\hline F. Limit portion size at mealtimes? & 5 & 1 & 5 \\
\hline $\begin{array}{ll}\text { I. Restrict consumption by adults In order for } \\
\text { small children to eat? }\end{array}$ & 3 & 2 & 6 \\
\hline $\begin{array}{l}\text { J. Feed working members at the expense of } \\
\text { non-working members? }\end{array}$ & 0 & 2 & 0 \\
\hline I. Reduce number of meals eaten in a day? & 2 & 4 & 8 \\
\hline J. Skip entire day without a eating? & 0 & 4 & 0 \\
\hline K. Getting relief food /money at church? & 0 & 4 & $\mathbf{0}$ \\
\hline Total Household Score & 16 & & 29 \\
\hline
\end{tabular}

Source: Household Survey, 2015

Annex II: CSI score of households with a visual type of disability member $(\mathrm{N}=52)$

\begin{tabular}{|r|c|c|c|}
\hline $\begin{array}{l}\text { In the past seven days, If there have been times when } \\
\text { you did not have enough food or money to buy food, } \\
\text { how often has your household had to: }\end{array}$ & $\begin{array}{c}\text { Raw } \\
\text { score }\end{array}$ & $\begin{array}{c}\text { Severity } \\
\text { weight }\end{array}$ & $\begin{array}{c}\text { Weighted score } \\
\text { = Frequency } \\
\text { weight }\end{array}$ \\
\hline $\begin{array}{r}\text { A. Rely on less preferred and less expensive } \\
\text { foods? }\end{array}$ & 6 & 1 & 6 \\
\hline B. Getting relief food/money at church? & 1 & 4 & 4 \\
\hline C. Borrow food, or rely on help from a friend or \\
relative?
\end{tabular}




\begin{tabular}{|c|c|c|c|c|}
\hline & Limit portion size at mealtimes? & 7 & 1 & 7 \\
\hline & $\begin{array}{l}\text { Restrict consumption by adults in order for } \\
\text { small children to eat? }\end{array}$ & 4 & 2 & 8 \\
\hline I. & $\begin{array}{l}\text { Feed working members at the expense of } \\
\text { non-working members? }\end{array}$ & 2 & 2 & 4 \\
\hline $\mathrm{J}$. & Reduce number of meals eaten in a day? & 4 & 4 & 16 \\
\hline & Skip entire day without a eating? & 1 & 4 & 4 \\
\hline & Total Household Score & & & 85 \\
\hline
\end{tabular}

Source: Household Survey, 2015

Annex III: CSI score of households with a visual type of disability member $(\mathrm{N}=18)$

\begin{tabular}{|c|c|c|c|}
\hline $\begin{array}{l}\text { In the past seven days, If there have been times when } \\
\text { you did not have enough food or money to buy food, } \\
\text { how often has your household had to: }\end{array}$ & $\begin{array}{c}\text { Raw } \\
\text { score }\end{array}$ & $\begin{array}{c}\text { Severity } \\
\text { weight }\end{array}$ & $\begin{array}{c}\text { Weighted score } \\
\text { Frequency } \\
\text { weight }\end{array}$ \\
\hline A. Rely on less preferred and less expensive foods? & 5 & 1 & 5 \\
\hline B. Getting relief food/money at church? & 1 & 4 & 4 \\
\hline C. $\quad \begin{array}{l}\text { Borrow food, or rely on help from a friend or } \\
\text { relative? }\end{array}$ & 3 & 2 & 6 \\
\hline D. $\quad$ Purchase food on credit? & 3 & 2 & 6 \\
\hline E. Send household members to eat elsewhere? & 2 & 2 & 4 \\
\hline F. Begging at street? & 2 & 4 & 8 \\
\hline G. Limit portion size at mealtimes? & 6 & 1 & 6 \\
\hline H. Restrict consumption by adults in order for small \\
$\quad$ children to eat?
\end{tabular}

Source: Household Survey, 2015

Annex IV: CSI Score of households with a speech and/or hearing type of disability member (10)

\begin{tabular}{|c|c|c|c|}
\hline $\begin{array}{l}\text { In the past seven days, If there have been times when } \\
\text { you did not have enough food or money to buy food, } \\
\text { how often has your household had to: }\end{array}$ & $\begin{array}{c}\text { Raw } \\
\text { score }\end{array}$ & $\begin{array}{c}\text { Severity } \\
\text { weight }\end{array}$ & $\begin{array}{c}\text { Weighted score } \\
\text { = Frequency * } \\
\text { weight }\end{array}$ \\
\hline $\begin{array}{c}\text { A. Rely on less preferred and less expensive } \\
\text { foods? }\end{array}$ & 5 & 1 & 5 \\
\hline
\end{tabular}


Fiseha Endale and Degefa Tolossa

\begin{tabular}{|c|c|c|c|c|}
\hline B. & $\begin{array}{l}\text { Borrow food, or rely on help from a friend or } \\
\text { relative? }\end{array}$ & 2 & 2 & 4 \\
\hline C. & Getting relief food/money at church? & 1 & 4 & 4 \\
\hline D. $\quad$ Purchase food on credit? & 3 & 2 & 6 \\
\hline E. $\quad$ Send household members to eat elsewhere? & 1 & 2 & 2 \\
\hline F. $\quad$ Begging at street? & 1 & 4 & 4 \\
\hline G. $\quad$ Limit portion size at mealtimes? & 5 & 1 & 5 \\
\hline H. $\quad \begin{array}{l}\text { Restrict consumption by adults In order for } \\
\text { small children to eat? }\end{array}$ & 4 & 2 & 8 \\
\hline I. $\quad \begin{array}{l}\text { Feed working members at the expense of } \\
\text { non-Working members? }\end{array}$ & 1 & 2 & 2 \\
\hline J. & Reduce number of meals eaten in a day? & 4 & 4 & 16 \\
\hline K. & Skip entire day without a eating? & 0 & 4 & 0 \\
\hline & $\quad$ Total Household Score & & 56 \\
\hline
\end{tabular}

Source: Household Survey, 2015 